\title{
Plant and mud extracts use for health purposes
}

\section{Romulus Rizon ${ }^{1}$}

\author{
${ }^{1}$ Secondary School “General Eremia Grigorescu”, Bucharest, Romania
}

\begin{abstract}
Agents derived from plants include anti-inflammatory flavonoids, terpenes, quinones, catechins, alkaloids, etc., all of which are known to modulate the expression of proinflammatory signals. Aspirin, a cornerstone for the treatment of inflammation-associated diseases, was derived from the salicylic acid found in the bark of the willow tree (Spiraea ulmaria, Salix species). The plant kingdom has kept offering remedies for humans from time immemorial. Nearly a quarter of our current drug arsenal is from higher plants. Plants are still a major source for discovery of new lead compounds for the pharmaceutical industry. During the last two decades, nearly $50 \%$ of the newly introduced drugs are of plant origin or analogues thereof.
\end{abstract}

Key words: radiological scores, RA, narrowing, erossions.

As potency is a rare trait of phytochemicals, bioprospecting is gradually overridden by the more holistic and integral view of using plant mixtures, extracts or partially purified extracts. Researchers have started discovering traditional and ethnomedicine anew. By 2016, the global nutraceutical market will exceed 207 billion U.S. dollars.

We now know hundreds of genes that regulate inflammation in model organisms. This vast amount of information yields increased power for personalized and stratified medicine, for identifying new biomarkers and for drug development. Overall, it gives us a blueprint (albeit still imperfect) of how inflammation is controlled that we can use to potentially manipulate the inflammatory process, whatever its underlying molecular mechanisms may be.

The physical and chemical characterisation of plant extracts, whose biomedical properties are generated by combining various chemical elements with biological structural components, is a strong argument for interdisciplinarity. The study at systemic and at the cellular and molecular level aims the interdisciplinary interaction of biochemists and biologists with mathematicians in the analysis and interpretation of experimentally obtained data. The clinical trial involves interdisciplinary and transdisciplinary interaction of doctors, biologists from clinical laboratories and mathematicians that will need to process the data obtained and together with the rest of the team to interpret these in a medical and biological manner to bring valid scientific arguments for the therapeutically useful hypothesis of the new anti-inflammatory products developed within the project.

Garlic (Allium sativum) play a role as antibiotic, anticancer, blood thinning, antiviral, antifungal and help in the fight against high blood pressure, high cholesterol, AIDS, arthritis, diabetes, influenza, leprosy and tuberculosis [4]. The health effects of garlic are attributed to the organosulfur compounds found in crushed cloves. Allicin is chemically unstable and degrades and rearranges over time to form a second generation allyl sulfides and polysulfides [5], which can be isolated by steam distillation or oil extraction. They have an inhibitory effect on the production of the pro-inflammatory mediators $\mathrm{NO}$ and PGE2 and also suppress iNOS and COX-2 expression in the macrophage cultures and 
also, the levels of IL-1b, IL-6, and TNF-a mRNAs were attenuated in RAW 264.7 macrophages [6]. Thiacremonone was the isolated active compound from heated garlic juice treated at $130 \mathrm{o} \mathrm{C}$ for $2 \mathrm{~h}$ [7]. In vivo studies showed that topical application of thiacremonone suppressed the 12-O-tetradecanoylphorbol-13-acetateinduced ear edema, the carrageenan and mycobacterium butyricum induced inflammatory and arthritic responses.

Capsaicin from chili pepper (Capsicum annum) produces highly selective regional anesthesia by causing degeneration of capsaicin-sensitive nociceptive nerve endings which can produce significant and long-lasting increases in nociceptive thresholds. Capsaicin potently activates transient receptor potential vanilloid 1 , which is a main receptor underlying nociception and it also inhibits NF-kB, thus producing an anti-inflammatory effect [8]. There are topical capsaicin formulations now available to treat post-herpetic neuralgia. Other uses have been studied for peripheral neuropathies and chronic musculoskeletal pain [9]. Hydrogel, solution, ointment and cream, microemulsion, transfersome, noisome, liposome and cubosome preparations of capsaicin have been documented in the literature to treat painrelated disorders such as rheumatoid arthritis, osteoarthritis, diabetic neuropathy, and postoperative pain [10].

The patent No. RO126913A0/2011 (Stan Adrian Viorel) describes the composition of a body massage cream with $32 \%$ water and mud from Techirghiol lake, $0.5 \%$ glycolic extract of ginger, $0.5 \%$ glycolic extract of rosemary leaves and $0.5 \%$ based organic iodine complex, along with the usual ingredients and excipients. Advantages of mud from the lake Techirghiol association with vegetable extracts obtained from ginger and rosemary have the following effects: antirheumatic, antiastenic, with synergistic properties in artrosis and inflammatory diseases.
The mud is composed by humic substances, pectin, cellulose and lignin, waxes, resins and inorganic materials [11], also being identified alkanes, 4 phenyl valeric acid, 5 isopentyl picolinic acid, 3 hydroxilauric acid, $(5 \alpha, 3 \beta)$ 3-hydroxy-11androstanon, $5 \alpha$-2-ene-11 androstenone, squalene, $\alpha$ terpineol, menthol derivates, palmitic acid, oleic and eicosanoic acid and izoprenoid phytan [12].

Humic compounds play a role in redox reactions, absorption, complexation and transport of substances, supporting structure and formation of mud and control the carbon biogeochemistry in ecosystems [13]. Humic acids have an astringent effect, adrenaline and dopamine receptor agonist, anti-allergic, antibacterial, anticoagulant, anti-inflammatory, antiviral, estrogen, hemostatic, hyperemic, UVBprotective [14] and are heavy metal chelating agents $[15,16,17]$.

Fulvic acids are oxidized substances with aromatic structures characterized by extensive lateral aliphatic chains having a lower nitrogen content compared to humic acids [18]. Fulvic acids have anti-allergic effect [19,20], antioxidant [21], antimicrobial [22], reduces cutaneous immune response [23], antitumoral [24] antiseptic [25], acting in acid medium by inhibiting mitochondrial respiration in Candida utilis [26], being used in the treatment of eczema [27], have antiulcerogenic properties [28] and precognitive so can be used to treat Alzheimer's disease [29].

Lipid fraction is 0.2 to $5 \%$ of the mud and include fatty acids, sterols, terpenes, hydrocarbons, chlorophyll, fats, waxes and resins [30]. Another fraction of mud consists in protein hydrolysates, amino acids, enzymes (amylase, arylsulfatase, bglucosidase, cellulase, chitinase, dehydrogenase, phosphatase, protease, urease) and carbohydrates [31].

For cellulite treatment extracted mud is mixed to form a cream with plant extracts and bioactive substances [32]. In psoriasis, seborrheic and atopic dermatitis, 
eczema and first degree burns is used a cream containing 1-6\% suspension of mud as active ingredient [33]. Combining the best fractions of mud obtained will result in getting the mud extract that will be used to obtain the new anti-inflammatory product. The experimental results to be obtained will determine the future direction of the marketing of products developed in the project.

\section{Conclusions}

The study determined for the first time in Romania the IL1 $\beta$ levels.

Radiological scores levels correlate directly proportional to the duration of the disease and clinical parameters, with scores DAS, HAQ and NAD, NAT repectively, laboratory parameters (rheumatoid factors, IgG, ESR, CRP); correlates inversely proportional with levels of immunological parameters (IL-1 $\beta$ ) and bone densitometry (T-score) which is in full accordance with the data in the literature.

\section{Bibliography}

1. Sharman A., Zhumadilov Z., 2011, The Scientific Basis for Healthy Aging and Antiaging Processes, New York

2. Recio M.C., Andújar I., Ríos J.L. AntiInflammatory Agents from Plants: Progress and Potential. Curr. Med. Chem., 2012, 19, 2088-2103

3. Munteanu C., 2012, Namolul terapeutic, Editura Balneara

4.http://www.rsc.org/chemistryworld/Issue s/2009/October/TheSpiceofLife.asp

5. Block, E.; Ahmad, S.; Catalfamo, J.L.; Jain, M. K.; Apitz-Castro, R. The chemistry of alkyl thiosulfinate esters. 9. Antithrombotic organosulfur compounds from garlic: structural, mechanistic, and synthetic studies. J. Am. Chem. Soc., 1986, 108 (22), 7045-7055.

6. Lee DY, Li H, Lim HJ, Lee HJ, Jeon R, Ryu J-H. Anti-Inflammatory Activity of Sulfur-Containing Compounds from Garlic. J. Med. Food. 2012;15(11):992999.
7. Woo KS, Hwang IG, Kim HY, Lee SH, Jeong HS. Physiological Activities of Thiacremonone Produced in High Temperature and High Pressure Treated Garlic. Preventive Nutrition and Food Science. 2016;21(1):68-72.

8. Ma X-L, Zhang F-X, Dong F, Bao L, Zhang $X$. Experimental evidence for alleviating nociceptive hypersensitivity by single application of capsaicin.Molecular Pain. 2015;11:22.

9. Maroon JC, Bost JW, Maroon A. Natural anti-inflammatory agents for pain relief. Surg. Neuro. Intl. 2010;1:80.

10. Peng $X$, Zhou $Y$, Han $K$, et al. Characterization of cubosomes as a targeted and sustained transdermal delivery system for capsaicin. Drug Design, Development and Therapy. 2015;9:42094218.

11. Wollina U. Peat: a natural source for dermatocosmetics and dermatotherapeutics.J Cutan Aesthet Surg. 2009 Jan;2(1):17-20.

12. Suárez M, González P, Domínguez R, Bravo A, Melián C, Pérez M, Herrera I, Blanco D, Hernández R, Fagundo JR. Identification of organic compounds in San Diego de los Baños Peloid (Pinar del Río, Cuba). J Altern Complement Med. 2011 Feb;17(2):155-65.

13.Grinhut T, Hadar Y, Chen Y (2007). Degradation and transformation of humic substances by saprotrophic fungi: processes and mechanisms. Fungi. Biol. Rev. 21: 179-89.

14.Flusser D, Abu-Shakra M, Friger M, Codish S, Sukenik S. Therapy with mud compresses for knee osteoarthritis: comparison of natural mud preparations with mineral-depleted mud. J Clin Rheumatol. 2002 Aug;8(4):197-203.

15. HUR J, LEE BM. Comparing the heterogeneity of copper-binding characteristics for two different-sized soil humic acid fractions using fluorescence quenching combined with 2D-COS. SCIENTIFICWORLDJOURNAL. 2011;11:1865-76. 
16. Yan M, Dryer D, Korshin GV, Benedetti MF. In situ study of binding of copper by fulvic acid: comparison of differential absorbance data and model predictions. Water Res. 2013 Feb 1;47(2):588-96.

17. Cao Y, Conklin M, Betterton E. Competitive complexation of trace metals with dissolved humic acid. Environ Health Perspect. 1995 Feb;103 Suppl 1:29-32.

18. Chilom G, Bruns AS, Rice JA (2009). Aggregation of humic acid in solution: Contributions of different fractions. Org Geochem. 40: 455-60.

19. Yamada P, Isoda H, Han JK, Talorete TP, Abe Y. Inhibitory effect of fulvic acid extracted from Canadian sphagnum peat on chemical mediator release by RBL-2H3 and KU812 cells. Biosci Biotechnol Biochem. 2007 May;71(5):1294-305.

20. Motojima H, O Villareal M, Han J, Isoda $\mathrm{H}$. Microarray analysis of immediate-type allergy in KU812 cells in response to fulvic acid. Cytotechnology. 2011 Mar;63(2):181-90.

21. Tachibana Y, Hiribe S, Tawa R. Studies of antioxidative activity of humic substances in peat (1). 2004, Trace Nutrients Res 23:104-108.

22. van Rensburg CEJ, van Straten A, Dekker J. An in vitro investigation of the antimicrobial activity of oxifulvic acid. $\mathrm{J}$ Antimicrob Chemother 2000, 46:853-854

23. Van Rensburg CEJ, Malfeld SCK, Dekker J. Topical application of oxifulvic acid suppresses the cutaneous immune response in mice. Drug Dev Res. 2001;53:29-32.

24. Kodama H; DENSO. Antitumor effect of humus extract on murine transplantable L1210 leukemia. J Vet Med Sci. 2007 Oct;69(10):1069-71.

25. Sherry L, Jose A, Murray C, Williams C, Jones B, Millington O, Bagg J, Ramage G. Carbohydrate Derived Fulvic Acid: An in vitro Investigation of a Novel Membrane Active Antiseptic Agent Against Candida albicans Biofilms. Front Microbiol. 2012;3:116.
26. Fujita $K$, Nagamine $Y$, Ping $X$, Taniguchi $M$. Mode of action of anhydrofulvic acid against Candida utilis ATCC 42402 under acidic condition. J Antibiot (Tokyo). 1999 Jul;52(7):628-34.

27. Gandy JJ, Snyman JR, van Rensburg CE. Randomized, parallel-group, doubleblind, controlled study to evaluate the efficacy and safety of carbohydratederived fulvic acid in topical treatment of eczema. Clin Cosmet Investig Dermatol. 2011;4:145-8.

28. Ghosal S, Singh SK, Kumar,Y. Shilajit. 3. Antiulcerogenic of fulvic acids and 4methoxy-6-carbomethoxybiphenyl isolated from shilaji," Phytotherapy Research,1988, vol. 2, no. 4, pp.187-191.

29. Carrasco-Gallardo C, Guzmán L, Maccioni RB. Shilajit: a natural phytocomplex with potential procognitive activity. Int J Alzheimers Dis. 2012;2012:674142.

30. Jandl, G, Schulten, H-R, Leinweber, P. Quantification of long-chain fatty acids in dissolved organic matter and soils. J. Plant Nutr. Soil Sci. 2002.165:133-139.

31. Makoi, J H J R,. Ndakidemi, P A. Selected soil enzymes: Examples of their potential roles in the ecosystem. Afr J Biotechnol, 2008. Vol. 7 (3), pp. 181-191. 32. Belipanni G., Topical formulation for the treatment of cellulite, EP 2197414 A1, 2010

33. Zeev M. et al. Cream composition comprising Dead Sea Mud, US 6582709 B1, 2003

34. Montes GC, Hammes N, Rocha MD, Montagnoli TL, Fraga CA,Barreiro EJ, Sudo RT , Zapata-Sudo G.Treatment with Adenosine Receptor Agonist Ameliorates Pain Induced by Acute and Chronic Inflammation. J Pharmacol Exp Ther. 2016 May 18. pii: jpet.115.231241. [Epub ahead of print]

35. Re R., Pellegrini N., Proteggente A., Pannala A., Yang M., Rice-Evans C. Antioxidant activity applying an improved ABTS radical cation decolorization assay. Free Radic. Biol. Med., 26: 1231-1237, 1999. 
36. Nourooz-Zadeh J., Tajaddini-Sarmadi J., Wolff S.P. Measurement of plasma hydroperoxide concentration by ferrous oxidation-xylenol orange assay in conjunction with triphenylphosphine. Anal. Biochem., 220: 403-409, 1994.

37. Charlton-Menys V., Liu Y., Durrington P.N. Semiautomated method for determination of serum paraoxonase activity using paraoxon as a substrate. Clin. Chem., 52: 453-457, 2006.

38. Browne R.W., Koury S.T., Marion S., Wilding G., Muti P., Trevisan M. Accuracy and biological variation of human serum paraoxonase I activity and polymorphism (Q192R) by kinetic enzyme assay. Clin. Chem., 53: 310-317, 2007.

39. Draganov D.I., Stetson P.L., Watson C.E., Billecke S.S., La Du B.N. Rabbit serum paraoxonase 3 (PON3) is a high density lipoprotein-associated lactonase and protects low density lipoprotein against oxidation. J. Biol. Chem., 275: 33435-33442, 2000.
40. Aebi H. Catalase in vitro. Methods Enzimol., 105: 121-126, 1984

41. Marklund S., Marklund G. Involvement of the superoxide anion radical in the autoxidation of pyrogallol and a convenient assay for superoxide dismutase. Eur. J. Biochem., 47: 469-474, 1974.

42. Carlberg I., Mannervik B. Glutathione reductase. Methods Enzymol., 113: 484491, 1985.

43. Brigelius-Flohe R., Wingler K., Muller C. Estimation of individual types of glutathione peroxidases. Methods Enzymol., 347: 101-113, 2002.

44. Habig W.H., Pabst M.J., Jakoby W.B. Glutathione S-transferase. The first enzymatic step in mercapturic acid formation. J. Biol. Chem., 249: 7130-7139, 1974 